\title{
Solid-phase interaction in $\mathrm{ZrO}_{2}-\mathrm{Fe}_{2} \mathrm{O}_{3}$ nanocrystalline system
}

\author{
S. A. Kirillova ${ }^{1}$, O. V. Almjasheva ${ }^{1}$, V. V. Panchuk ${ }^{2}$, V. G. Semenov ${ }^{2}$ \\ ${ }^{1}$ St. Petersburg State Electrotechnical University “LETI”, ul. Professora Popova, 5, St. Petersburg, 197376, Russia \\ ${ }^{2}$ St. Petersburg State University, Universitetskaya nab., 7-9, St. Petersburg, 199034, Russia \\ refractory-sveta@mail.ru, almjasheva@mail.ru,vitpan@mail.ru,val_sem@mail.ru
}

PACS 64.75.+g; 76.20.+q

DOI 10.17586/2220-8054-2018-9-6-763-769

Based on the results of X-ray phase analysis and Mössbauer spectroscopy, it was demonstrated that in the $\mathrm{ZrO}_{2}-\mathrm{Fe}_{2} \mathrm{O}_{3}$ system, represented by the mechanical mixture of $m-\mathrm{ZrO}_{2}(14 \pm 2 \mathrm{~nm})$ and $\alpha-\mathrm{Fe}_{2} \mathrm{O}_{3}(43 \pm 2 \mathrm{~nm})$ nanoparticles, being heated above the temperature corresponding to the melting temperature of the two-dimensional nonautonomous phase, transformation of $\alpha$-Fe ${ }_{2} \mathrm{O}_{3}$ occurs resulting in appearing of the X-ray amorphous magnetically disordered state localized on the surface of $\mathrm{ZrO}_{2}$ nanoparticles in the form of a thin layer. Transformation pattern in $\mathrm{ZrO}_{2}-\mathrm{Fe}_{2} \mathrm{O}_{3}$ nanocrystalline system has been introduced

Keywords: nanostructures, iron-zirconia, surface, X-ray diffraction, Mössbauer spectroscopy.

Received: 2 October 2018

Revised: 24 November 2018

\section{Introduction}

Interest in systems containing zirconium dioxide is caused by high refractory properties, strength, crack resistance, chemical inertness, superionic oxygen conductivity, biocompatibility, catalytic activity and other important characteristics of the materials, based on this substance [1,2]. Ceramic and composite materials, based on $\mathrm{ZrO}_{2}-$ $\mathrm{Fe}_{2} \mathrm{O}_{3}$ system, are widely used as catalysts or catalyst carriers for hydrocarbons isomerization, carbon monoxide hydrogenization, selective hydrogenation (Fischer-Tropsch reaction) and ammonia synthesis [3,4], as well as the magnetic materials $[5,6]$.

Different contradictory data, published in the scientific literature, are pertinent to possibilities and ranges of solid solutions formation in $\mathrm{ZrO}_{2}-\mathrm{Fe}_{2} \mathrm{O}_{3}$ system. The study of phase formation processes in the considered system is connected with definite methodological difficulties, related to the behavior of the studied system components [7-16].

While extremely localized areas of the iron oxide-based solid solutions in zirconium dioxide may exist for the macroscopic particles, as it follows from data [17-26] (which is most pronounced for the low-temperature range), more wide solubility range of iron oxide in $\mathrm{ZrO}_{2}$-based nanocrystals was detected, which is shown by data [27-36], in case of nano-scale particles. In this case, the possibility and the ranges of solid solutions existence in this system to a great degree are determined by the synthesis method of considered compositions.

Composition synthesis and subsequent study of their behavior during heating for $\mathrm{ZrO}_{2}-\mathrm{Fe}_{2} \mathrm{O}_{3}$ system are generally realized with application of sol-gel synthesis followed by the annealing-quenching heat treatment of received precursors [16,22-24,31-33]; hydrothermal synthesis [5]; thermal decomposition of iron (III) and zirconium salts [27]; $\mathrm{ZrO}_{2}$ impregnating with aqueous solution of ferric (III) nitrate and subsequent drying and incineration [3,4]; solid-phase synthesis method [25,37]; reaction media burning method (solid-phase flame method, solution burning) $[26,38,39]$, etc. [6,34-36].

Inconsistencies pertinent to ranges of solid solutions areas, a state of $\mathrm{ZrO}_{2}$ surface and iron ions location in different positions still exist and may be found almost in any new paper devoted to this system. Therefore, it is of interest to study the behavior of $\mathrm{ZrO}_{2}$ and $\mathrm{Fe}_{2} \mathrm{O}_{3}$ nano-scale particles during their thermal treatment.

\section{Experimental procedures}

In order to study the solid-phase interaction of the components, $\mathrm{ZrO}_{2}$ and $\mathrm{Fe}_{2} \mathrm{O}_{3}$ nano-scale powders, which have been obtained by hydrothermal treatment method (refer to [40]), were mixed in ethyl alcohol. Specimens were formed by pressing under pressure of $5 \mathrm{MPa}$, after which these specimens were heat treated in the air following the annealing-quenching mode with exposure during 30 minutes at temperatures of $800,900,1000$ and $1100{ }^{\circ} \mathrm{C}$.

The phase composition of the specimens was studied by X-ray phase analysis using XRD-7000 Shimadzu diffractometer $\left(\mathrm{Cu} K_{\alpha}\right.$-radiation). The X-ray diffraction pattern peak identification was performed using the PDWin 4.0 software solution and Crystallographica Search-Match package. Based on the data analysis pertinent to X-ray 
diffraction pattern peak tailing, the average crystalline particle size has been calculated. Calculation was performed using the Sherrer equation [41].

The specimens' elemental composition was determined by electron probe microanalysis using Hitachi S-570 scanning electron microscope, equipped with Bruker Quantax 200 microprobe system.

Exposure of Mössbauer spectra was realized using WISSEL spectrometer operating in the constant acceleration mode, at the room temperature and at the liquid nitrogen boiling point. ${ }^{57} \mathrm{Co}$ in Rh-matrix, characterized by the radioactivity of $30 \mathrm{mC}$, was used as the source. Mathematical treatment of the experimental spectra was performed using the MOSSFIT software package [42]. The spectrometer velocity scale was calibrated using $\alpha$-Fe foil at the room temperature. The chemical shift values were presented relative $\alpha$-Fe.

\section{Results and their discussion}

Results of X-ray phase analysis of specimens, containing $6.4 \pm 0.3$ and $9.0 \pm 0.6 \mathrm{~mol}^{\circ} \% \mathrm{FeO}_{1.5}$, which have been annealed at a temperature of $800,900,1000$ and $1100{ }^{\circ} \mathrm{C}$ over 30 minutes, are presented in Figs. $1(a)$ and 2(a). Initial specimens were represented by the mechanical mixture of preliminary received nano-scale powders of $\mathrm{ZrO}_{2}$ (monoclinic and tetragonal modification groups) and $\mathrm{Fe}_{2} \mathrm{O}_{3}$ [hematite, (104) peak, $I-100 \%$ ]. After heating at a temperature of $800-900{ }^{\circ} \mathrm{C}$, a decrease in the intensity of the $t-\mathrm{ZrO}_{2}$ peaks was observed, and after heating at a temperature above $900{ }^{\circ} \mathrm{C}$, diffractograms contained only those reflections, which corresponded to monoclinic modification group of $\mathrm{ZrO}_{2}$. For the specimen containing $6.4 \pm 0.3 \mathrm{~mol} . \% \mathrm{FeO}_{1.5}$, which was annealed at 800 and $900{ }^{\circ} \mathrm{C}$, a peak on diffractograms, corresponding to $\alpha-\mathrm{Fe}_{2} \mathrm{O}_{3}$, disappeared. During further increase of the thermal treatment temperature, (104) peak on diffractograms appeared again, however, its intensity was substantially less as compared with the initial composition. For the specimen, containing $9.0 \pm 0.6 \mathrm{~mol} . \% \mathrm{FeO}_{1.5}$, which has been annealed at a temperature of $800-900{ }^{\circ} \mathrm{C}$, the relative intensity of (104) peak on diffractograms decreased as compared with the initial composition, while at a temperature of $1000-1100^{\circ} \mathrm{C}$ the integral intensity of this peak has increased, becoming comparable with the initial composition.

It should be noted that sizes of $m-\mathrm{ZrO}_{2}$ crystallites during heating up to a temperature of $900{ }^{\circ} \mathrm{C}$ have changed only slightly both for the specimen, containing $6.4 \pm 0.3 \mathrm{~mol} . \% \mathrm{FeO}_{1.5}$ (Fig. 3), as well as for the specimen, containing $9.0 \pm 0.6 \mathrm{~mol} . \% \mathrm{FeO}_{1.5}$. Analysis of $m-\mathrm{ZrO}_{2}$ unit cell parameters dependence on temperature has demonstrated their invariability within the measurement accuracy (Fig. 4). Absence of variation of $\mathrm{ZrO}_{2}$ unit cell parameters may be indicative of the fact that heat treatment during 30 minutes at a temperature of up to 1000 and $1100{ }^{\circ} \mathrm{C}$ did result in $m-\mathrm{ZrO}_{2}$-based solid solution formation.

Mössbauer spectra for initial compositions of specimens, containing $6.4 \pm 0.3$ and $9.0 \pm 0.6 \mathrm{~mol}_{0} \% \mathrm{FeO}_{1.5}$, as well as for specimens, annealed at $800,900,1000$ and $1100{ }^{\circ} \mathrm{C}$, are presented in Figs. 1(b) and 2(b), respectively. The results of experimental spectra analysis with detection of sextet and doublet components, corresponding to iron atoms in magnetically ordered and magnetically disordered phases, are also presented in Figs. 1(b) and 2(b). Mössbauer parameters for sextet and doublet components of the iron-containing phases are presented in Table 1. The quantitative estimation of the iron relative content in different phases was performed with precision determined by difference in values of $f_{M}$ Mössbauer factor (probability of resonance absorption in each phase).

For the initial specimens, which were represented by the mechanical mixture of the preliminary produced $t$-, $m-\mathrm{ZrO}_{2}$ and $\alpha-\mathrm{Fe}_{2} \mathrm{O}_{3}$ nano-scale powders, the Mössbauer spectrum was characterized by sextet, parameters of which have corresponded to the sextet parameters for $\alpha-\mathrm{Fe}_{2} \mathrm{O}_{3}$ [43].

For the specimens being thermally treated at $800{ }^{\circ} \mathrm{C}$, the Mössbauer spectrum was characterized by doublet $\left(6.4 \pm 0.3 \mathrm{~mol} \% \mathrm{FeO}_{1.5}\right)$ or doublet and sextet superposition $\left(9.0 \pm 0.6 \mathrm{~mol}^{\circ} \% \mathrm{FeO}_{1.5}\right)$. It should be noted that for the specimen containing 6.4 mol.\% $\mathrm{FeO}_{1.5}$ only doublet components have been commonly observed, while these doublet components are incidental to the atoms of iron in $3+$ oxidation rate located in the form of thin layer on the surface of another oxide $[44,45]$. With a temperature increase, the sextet appeared again and the doublet share in experimental spectrum has decreased; at a temperature of $1100{ }^{\circ} \mathrm{C}$ a share of the magnetically disordered phase was about $23 \%$. Such an effect was observed in case of increasing of particles sizes [43]. For the specimen, containing $9.0 \mathrm{~mol} . \% \mathrm{FeO}_{1.5}$, the sextet component is common for the whole heat treatment temperature range.

While comparing the data of X-ray phase analysis and Mssbauer spectroscopy, it may be concluded, that at a temperature of $800{ }^{\circ} \mathrm{C}$, transformation of $\alpha-\mathrm{Fe}_{2} \mathrm{O}_{3}$ begins, which results in its transfer into X-ray amorphous magnetically disordered phase, localized on the surface of zirconium dioxide particles, as shown by the absence of (104) $\alpha-\mathrm{Fe}_{2} \mathrm{O}_{3}$ peak on the diffractogram, by sextet disappearance and doublet appearance in Mössbauer spectrum of the specimen, containing $6.4 \pm 0.3 \mathrm{~mol} . \% \mathrm{FeO}_{1.5}$. With increased thermal treatment temperatures, the sizes of $m-\mathrm{ZrO}_{2}$ particles are increased (Fig. 3) that causes decrease of their surface area and, therefore, aggregation of the iron oxide surface layer, accompanied with $\alpha-\mathrm{Fe}_{2} \mathrm{O}_{3}$ bulk phase particles formation. Formation of $\alpha-\mathrm{Fe}_{2} \mathrm{O}_{3}$ particles is confirmed by the data of X-ray phase analysis and Mössbauer spectroscopy, i.e. (104) $\alpha-\mathrm{Fe}_{2} \mathrm{O}_{3}$ peak 


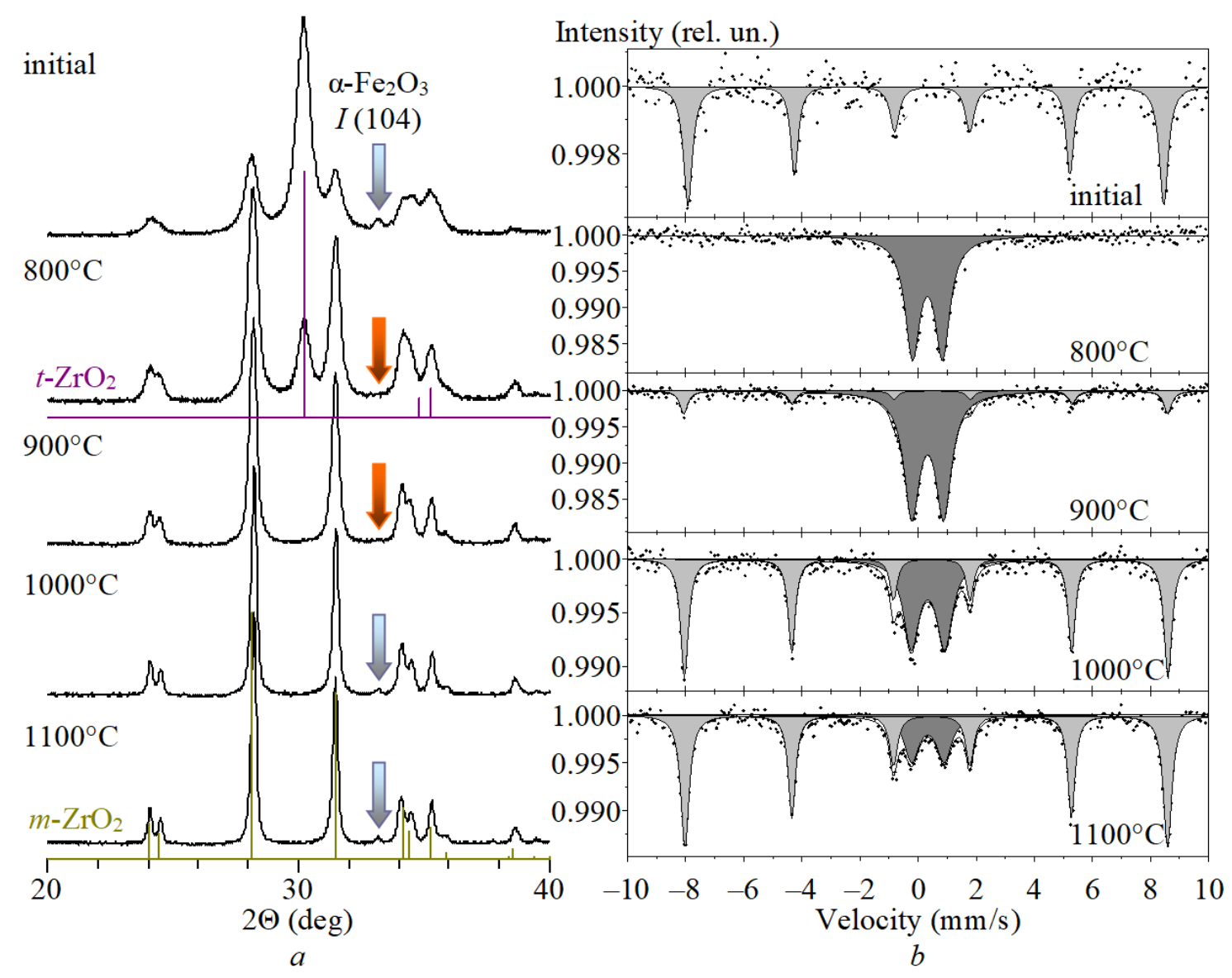

FIG. 1. X-ray diffractograms $(a)$ and Mössbauer spectra series, measured at $25{ }^{\circ} \mathrm{C}(b)$ of the specimen, containing $6.4 \pm 0.3 \mathrm{~mol} \% \mathrm{FeO}_{1.5}$, which has been annealed at a temperature of 800 , 900,1000 and $1100{ }^{\circ} \mathrm{C}$ during 30 minutes

on the diffractogram appears again, in Mössbauer spectrum for the specimen, containing $6.4 \pm 0.3 \mathrm{~mol}^{\circ} \% \mathrm{FeO}_{1.5}$ sextet corresponding to $\alpha-\mathrm{Fe}_{2} \mathrm{O}_{3}$, may be revealed against the doublet background.

Apparently, during thermal treatment at a temperature of 800 and $900{ }^{\circ} \mathrm{C}$ with exposure for 30 minutes, $\alpha$ $\mathrm{Fe}_{2} \mathrm{O}_{3}$ is transformed with the formation of the iron oxide layer on a surface of $\mathrm{ZrO}_{2}$ nanoparticles. At temperatures of $800-900{ }^{\circ} \mathrm{C}$, for $\alpha-\mathrm{Fe}_{2} \mathrm{O}_{3}$ are corresponding to the melting temperature of the surface (two-dimensional nonautonomous) phase [46]. It appears that transfer of the two-dimensional nonautonomous phase into a liquid (liquid-like) state initiates active mass transfer of the iron-containing component to a surface of $\mathrm{ZrO}_{2}$ nanoparticles. It should be noted that similar processes were observed earlier in $\mathrm{BeO}-\mathrm{Fe}_{2} \mathrm{O}_{3}, \mathrm{MgO}-\mathrm{Fe}_{2} \mathrm{O}_{3}, \mathrm{Al}_{2} \mathrm{O}_{3}-\mathrm{Fe}_{2} \mathrm{O}_{3}, \mathrm{SiO}_{2}-$ $\mathrm{Fe}_{2} \mathrm{O}_{3}$ systems [44, 45]. The transformation pattern, corresponding to the described processes in $\mathrm{ZrO}_{2}-\mathrm{Fe}_{2} \mathrm{O}_{3}$ system, in which zirconium dioxide is initially represented by $m-\mathrm{ZrO}_{2}$ and by $\alpha-\mathrm{Fe}_{2} \mathrm{O}_{3}$ nanoparticles, characterized by the crystallites sizes of $14 \pm 2 \mathrm{~nm}$ and $43 \pm 2 \mathrm{~nm}$, respectively, is presented in Fig. 5 .

\section{Conclusion}

As distinct from the cases, in which compositions are received via codeposition, hydrothermal synthesis, etc., and in which mixing of components is initially possible at the atomic level, in the case of the solid-phase interaction of the nano-scale particles in $\mathrm{ZrO}_{2}-\mathrm{Fe}_{2} \mathrm{O}_{3}$ system in the range of low contents of the iron-containing component increasing of the treatment temperature up to $800-900{ }^{\circ} \mathrm{C}$ does not cause stabilization of zirconium dioxide tetragonal modification and the formation of tetragonal solid solution, as well as $\mathrm{Fe}^{3+}$ ions are not included into $m-\mathrm{ZrO}_{2}$ structure.

During the thermal treatment of $\mathrm{ZrO}_{2}$ and $\mathrm{Fe}_{2} \mathrm{O}_{3}$ nanoparticles, at definite critical value of temperature in range of $800-900{ }^{\circ} \mathrm{C}, \alpha-\mathrm{Fe}_{2} \mathrm{O}_{3}$ transformation occurs with thin layer formation on $m-\mathrm{ZrO}_{2}$ nanoparticles surface, i.e. formation of the composite nanoparticles of "nucleus $\left(m-\mathrm{ZrO}_{2}\right.$ nanoparticles) - shell (amorphous $\left.\mathrm{Fe}_{2} \mathrm{O}_{3}\right)$ " type takes place. 


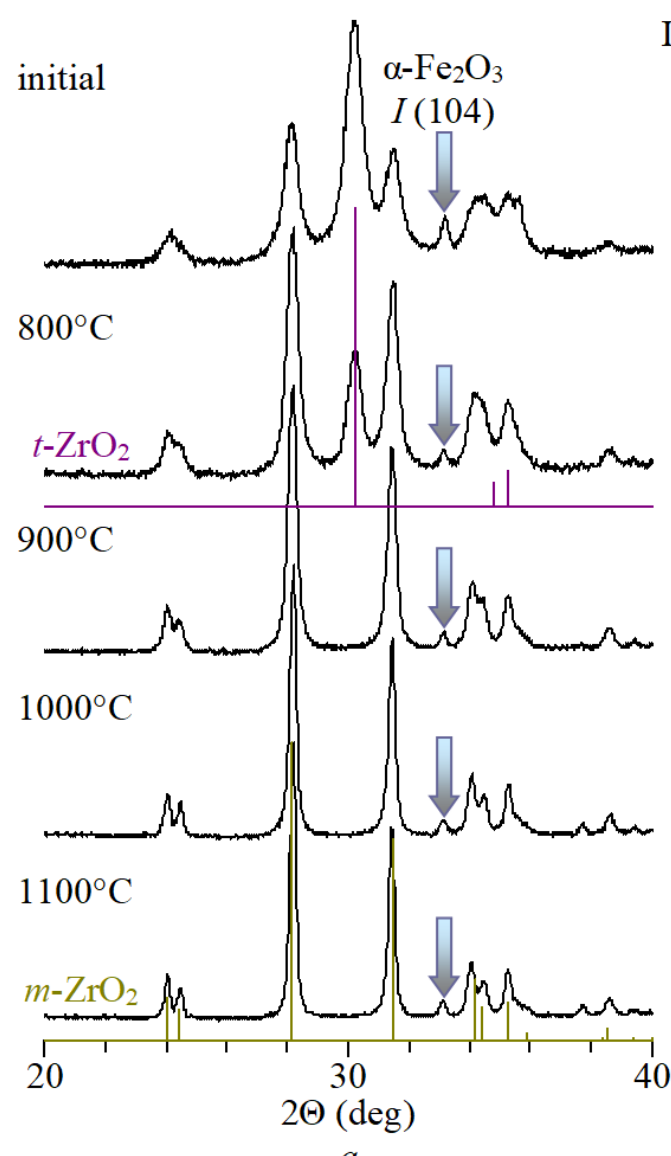

Intensity (rel. un.)

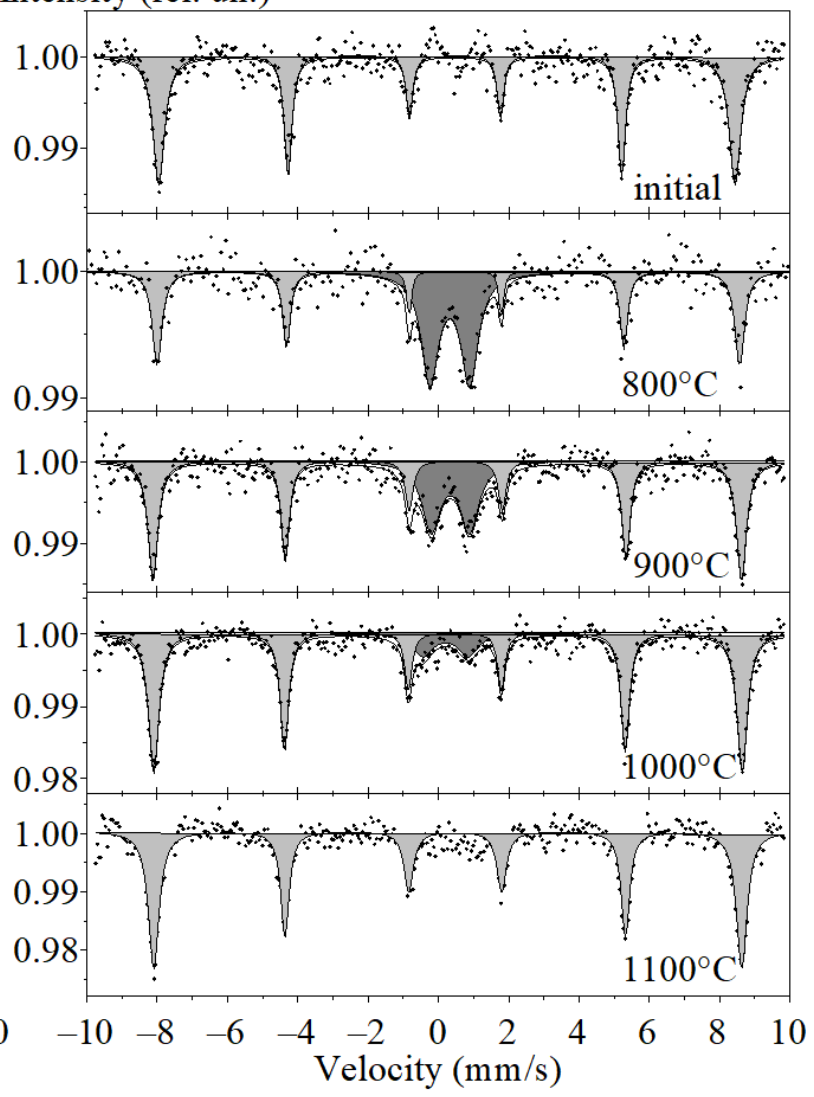

$a$

$$
\text { b }
$$

FIG. 2. X-ray diffractograms $(a)$ and Mössbauer spectra series, measured at $25{ }^{\circ} \mathrm{C}(b)$ of the specimen, containing $9.0 \pm 0.6$ mol.\% $\mathrm{FeO}_{1.5}$, which has been annealed at a temperature of 800 , 900,1000 and $1100{ }^{\circ} \mathrm{C}$ during 30 minutes

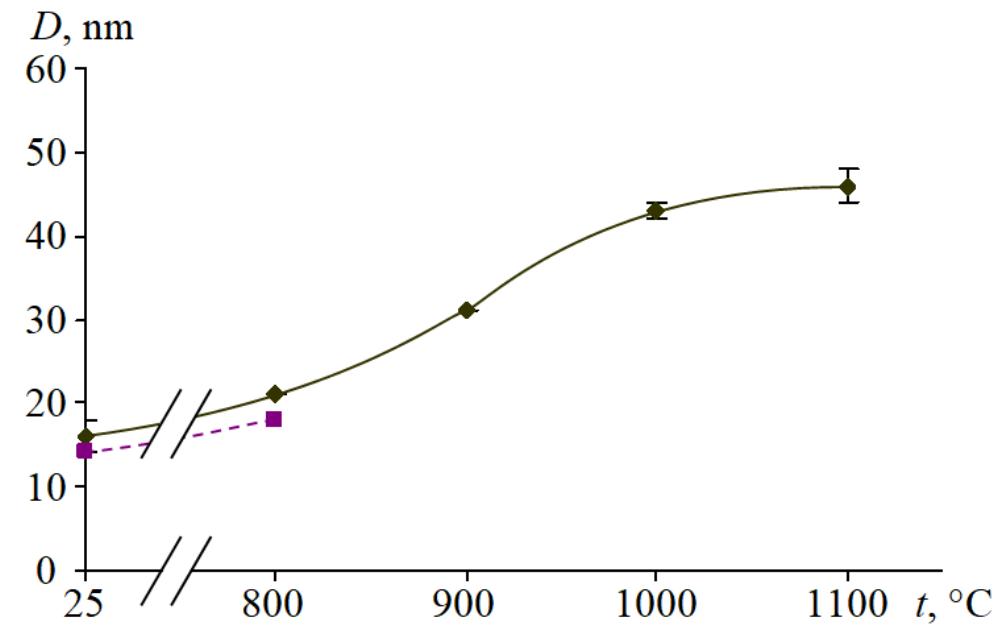

FIG. 3. $t-\mathrm{ZrO}_{2}(\square)$ and $m-\mathrm{ZrO}_{2}(\diamond)$ crystallites sizes dependence on the heat treatment temperature for the specimen, containing $6.4 \pm 0.3 \mathrm{~mol} . \% \mathrm{FeO}_{1.5}$ 


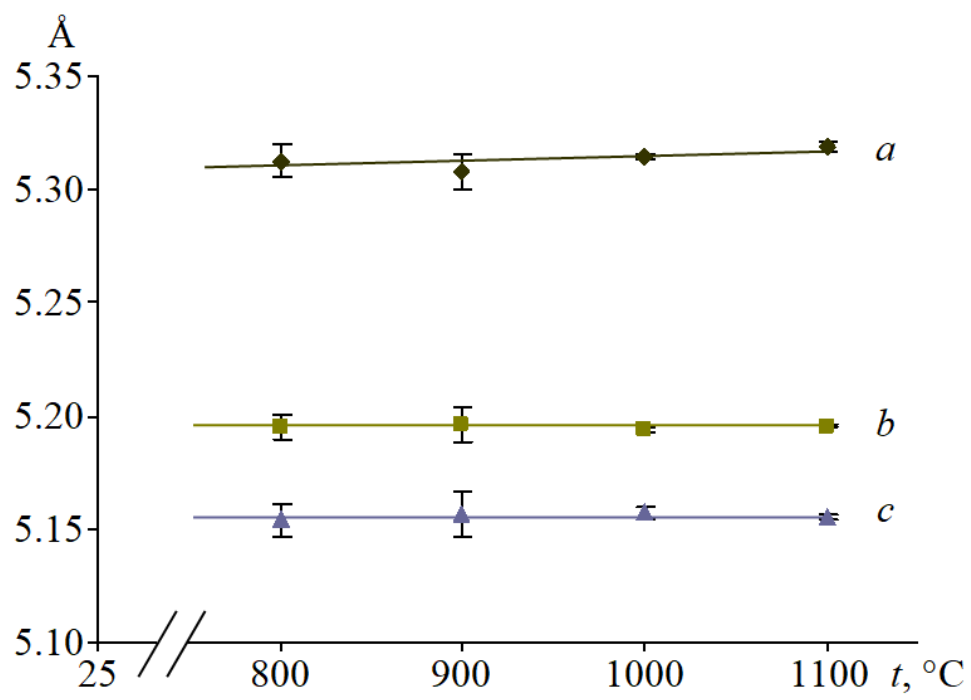

FIG. 4. $m-\mathrm{ZrO}_{2}$ unit cell parameters dependence on the heat treatment temperature for the specimen, containing $6.4 \pm 0.3 \mathrm{~mol} \% \mathrm{FeO}_{1.5}$

TABLE 1. Mössbauer parameters of spectra, measured for the studied specimens at a temperature of $25^{\circ} \mathrm{C}$

\begin{tabular}{|c|c|c|c|c|c|c|c|}
\hline \multirow{3}{*}{$\begin{array}{c}\mathrm{FeO}_{1.5} \\
\text { content, } \\
\text { mol. } \%\end{array}$} & \multirow{3}{*}{$\begin{array}{c}\text { Annealing } \\
\text { tempera- } \\
\text { ture, }{ }^{\circ} \mathrm{C}\end{array}$} & \multicolumn{6}{|c|}{ Parameters of Mössbauer spectra } \\
\hline & & \multicolumn{3}{|c|}{ sextet } & \multicolumn{2}{|c|}{ doublet } & \multirow{2}{*}{$\begin{array}{c}\text { Paramagnetic } \\
\text { component } \\
\text { content, } \%\end{array}$} \\
\hline & & $\begin{array}{c}\text { Isomer } \\
\text { shift, mm/s }\end{array}$ & $\begin{array}{c}\text { Quadrupole } \\
\text { splitting, } \mathrm{mm} / \mathrm{s}\end{array}$ & $\begin{array}{l}\text { Effective } \\
\text { field, } T\end{array}$ & $\begin{array}{c}\text { Isomer } \\
\text { shift, } \mathrm{mm} / \mathrm{s}\end{array}$ & $\begin{array}{c}\text { Quadrupole } \\
\text { splitting, } \mathrm{mm} / \mathrm{s}\end{array}$ & \\
\hline \multirow{5}{*}{$6.4 \pm 0.3$} & - & $0.378 \pm 0.013$ & $0.218 \pm 0.026$ & $50.871 \pm 0.099$ & - & - & 0 \\
\hline & 800 & - & - & - & $0.326 \pm 0.000$ & $1.032 \pm 0.000$ & 100 \\
\hline & 900 & $0.375 \pm 0.018$ & $0.221 \pm 0.037$ & $51.734 \pm 0.122$ & $0.331 \pm 0.000$ & $1.092 \pm 0.011$ & 84.85 \\
\hline & 1000 & $0.376 \pm 0.005$ & $0.188 \pm 0.010$ & $51.693 \pm 0.038$ & $0.340 \pm 0.014$ & $1.152 \pm 0.029$ & 41.51 \\
\hline & 1100 & $0.376 \pm 0.004$ & $0.185 \pm 0.007$ & $51.594 \pm 0.028$ & $0.337 \pm 0.021$ & $1.123 \pm 0.042$ & 22.62 \\
\hline \multirow{5}{*}{$9.0 \pm 0.6$} & - & $0.357 \pm 0.005$ & $0.228 \pm 0.010$ & $50.905 \pm 0.040$ & - & - & 0 \\
\hline & 800 & $0.383 \pm 0.016$ & $0.192 \pm 0.033$ & $51.458 \pm 0.136$ & $0.324 \pm 0.042$ & $1.128 \pm 0.080$ & 52.54 \\
\hline & 900 & $0.374 \pm 0.008$ & $0.240 \pm 0.015$ & $51.984 \pm 0.060$ & $0.342 \pm 0.040$ & $1.093 \pm 0.078$ & 35.01 \\
\hline & 1000 & $0.372 \pm 0.005$ & $0.193 \pm 0.009$ & $51.976 \pm 0.037$ & $0.203 \pm 0.077$ & $1.292 \pm 0.169$ & 14.18 \\
\hline & 1100 & $0.373 \pm 0.006$ & $0.211 \pm 0.011$ & $51.938 \pm 0.044$ & $0.193 \pm 0.087$ & $1.282 \pm 0.179$ & $\sim 5$ \\
\hline
\end{tabular}

\section{Acknowledgements}

The authors express their gratitude to V. V. Gusarov for the attention he paid to the work and for his help in the interpretation of the results.

This work was supported by Ministry of education and science of the Russian Federation (Project 3.6522.2017). 


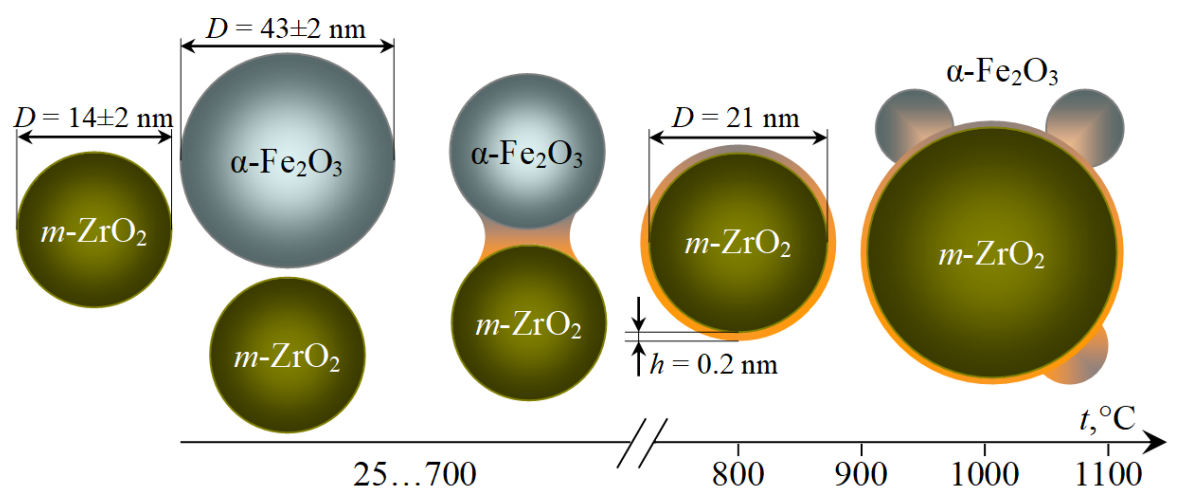

FIG. 5. Transformation pattern in $\mathrm{ZrO}_{2}-\mathrm{Fe}_{2} \mathrm{O}_{3}$ system

\section{References}

[1] Shackelford J.F., Doremus R.H. Ceramic and Glass Materials. Structure, Properties and Processing. Springer, Boston, MA, 2008, 209 p.

[2] Almjasheva O.V., Garabadzhiu A.V., Kozina Yu.V., et al. Biological effect of zirconium dioxide-based nanoparticles. Nanosystems: Phys. Chem. Math., 2017, 8 (3), P. 391-396.

[3] Chen K., Dong L., Yan Q., Chen Y. Dispersion of $\mathrm{Fe}_{2} \mathrm{O}_{3}$ supported on metal oxides studied by Mssbauer spectroscopy and XRD. J. Chem. Soc., Faraday Trans., 1997, 93 (12), P. 2203-2206.

[4] Okamoto Y., Kubota T., Ohto Y., Nasu S. Metal Oxide-Support Interactions in Fe/ZrO 2 Catalysts. J. Phys. Chem. B, 2000, 104 (35), P. 8462-8470.

[5] Kuryliszyn-Kudelska I., Arciszewska M., Maolepszy A., et al. Influence of Fe doping on magnetic properties of $\mathrm{ZrO}_{2}$ nanocrystals. $J$. Alloys Compd., 2015, 632, P. 609-616.

[6] de Souza A.O., Ivashita F.F., Biondo V., et al. Structural and magnetic properties of iron doped $\mathrm{ZrO}_{2}$. J. Alloys Compd., 2016, 680, P. 701-710.

[7] Belov G.V., Iorish V.S., Yungman V.S. IVTANTHERMO for Windows - database on thermodynamic properties and related software. Calphad: Comput. Coupling Phase Diagrams Thermochem., 1999, 23 (2), P. 173-180.

[8] Srinivasan R., Davis B.H., Burl C.O., Hubbard C.R. Crystallization and phase transformation process in zirconia: an in situ hightemperature X-ray diffraction study. J. Am. Ceram. Soc., 1992, 75 (5), P. 1217-1222.

[9] Oleinikov N.N., Pentin I.V., Murav'eva G.P., Ketsko V.A. Highly disperse metastable $\mathrm{ZrO}_{2}$-based phases. Russ. J. Inorg. Chem., 2001, 46 (9), P. 1275-1281.

[10] Guo X., Schober T. Water incorporation in tetragonal zirconia. J. Am. Ceram. Soc., 2004, 87 (4), P. $746-748$.

[11] Shukla S., Seal S. Mechanisms of room temperature metastable tetragonal phase stabilisation in zirconia. Int. Mater. Rev., 2005, 50 (1), P. 45-64.

[12] Zhang F., Chupas P.J., Lui S.L.A., et al. In situ study of the crystallization from amorphous to cubic zirconium oxide: Rietveld and reverse Monte Carlo analyses. Chem. Mater., 2007, 19 (13), P. 3118-3126.

[13] Lin F.-Q., Dong W.-S., Liu C.-L., et al. In situ source-template-interface reaction route to hollow $\mathrm{ZrO}_{2}$ microspheres with mesoporous shells. J. Colloid Interface Sci., 2008, 323 (2), P. 365-371.

[14] Almjasheva O.V. Heat-stimulated transformation of zirconium dioxide nanocrystals produced under hydrothermal conditions. Nanosystems: Phys. Chem. Math., 2015, 6 (5), P. 697-703.

[15] Li F., Li Y., Song Z., et al. Evolution of the crystalline structure of zirconia nanoparticles during their hydrothermal synthesis and calcination: Insights into the incorporations of hydroxyls into the lattice. J. Eur. Ceram. Soc., 2015, 35 (8), P. $2361-2367$.

[16] Li P., Chen I-W., Penner-Hahn J.E. Effect of dopants on zirconia stabilization - An X-ray Absorption Study: I, Trivalent Dopants. J. Am. Ceram. Soc., 1994, 77 (1), P. 118-128.

[17] Muan A. Phase equilibria at high temperatures in oxide systems involving changes in oxidation states. Am. Jour. Sci., 1958, 256 (3), P. 171-207.

[18] Jones T., Kimura S., Muan A. Phase Relations in the System FeO-Fe $\mathrm{O}_{3}-\mathrm{ZrO}_{2}-\mathrm{SiO}_{2}$. J. Am. Ceram. Soc., 1967,50 (3), P. $137-142$.

[19] Petrov Yu.B., Udalov Yu.P., Slovak J., Morozov Yu.G. Liquid immiscibility phenomena in melts of the $\mathrm{ZrO}_{2}-\mathrm{FeO}_{-} \mathrm{Fe}_{2} \mathrm{O}_{3} \mathrm{System}_{\text {. Glass }}$ Phys. Chem., 2002, 28 (3), P. 139-146.

[20] Bechta S.V., Krushinov E.V., Al'myashev V.I., et al. Phase relations in the $\mathrm{ZrO}_{2}-\mathrm{FeO}$ system. Russ. J. Inorg. Chem., 2006, 51 (2), P. 325-331.

[21] Bechta S.V., Krushinov E.V., Almjashev V.I., et al. Phase diagram of the $\mathrm{ZrO}_{2}-\mathrm{FeO}$ system. J. Nucl. Mater., 2006,348 (1-2), P. 114-121.

[22] Popović S., Gržeta B., Czakó-Nagy I., Musić S. Structural properties of the system m- $\mathrm{ZrO}_{2}-\alpha$-Fe ${ }_{2} \mathrm{O}_{3}$. J. Alloys Compd., 1996, 241 (1-2), P. $10-15$.

[23] Kriventsov V.V., Kochubey D.I., Maximov Yu.V., et al. Structural determination of the Fe-modified zirconium oxide. Nucl. Instrum. Methods Phys. Res., Sect. A, 2001, 470 (1-2), P. 341-346.

[24] Navo J.A., Hidalgo M.C., Coln G., et al. Preparation and Physicochemical Properties of $\mathrm{ZrO}_{2}$ and Fe/ZrO 2 Prepared by a Sol-Gel Technique. Langmuir, 2001, 17 (1), P. 202-210.

[25] Beck H.P., Kaliba C. On the solubility of Fe, $\mathrm{Cr}$ and $\mathrm{Nb}$ in $\mathrm{ZrO}_{2}$ and its effect on thermal dilatation and polymorphic transition. Mater. Res. Bull., 1990, 25 (9), P. 1161-1168. 
[26] Ghigna P., Spinolo G., Anselmi-Tamburini U., et al. Fe-Doped Zirconium Oxide Produced by Self-Sustained High-Temperature Synthesis: Evidence for an Fe-Zr Direct Bond. J. Am. Chem. Soc., 1999, 121 (2). P. 301-307.

[27] Davison S., Kershaw R., Dwight K., Wold A. Preparation and characterization of cubic $\mathrm{ZrO}_{2}$ stabilized by Fe(III) and Fe(II). J. Solid State Chem., 1988, 73 (1), P. 47-51.

[28] Inwang I.B., Chyad F., McColm I.J. Crystallisation of iron(III)-zirconia co-gels. J. Mater. Chem., 1995, 5 (8), P. $1209-1213$.

[29] Berry F.J., Loretto M.H., Smith M.R. Iron-zirconium oxides: An investigation of structural transformations by X-ray diffraction, electron diffraction, and iron-57 Mössbauer spectroscopy. J. Solid State Chem., 1989, 83 (1), P. 91-99.

[30] Berry F.J., Jobsen S., Smith M.R. Iron-zirconium oxide catalysts for the hydrogenation of carbon monoxide: In situ studies by iron-57 Mössbauer spectroscopy. Hyperfine Interact., 1989, 46 (1), P. 607-611.

[31] Štefanić G., Musić S., Popović S., Nomura K. A study of the $\mathrm{ZrO}_{2}-\mathrm{Fe}_{2} \mathrm{O}_{3}$ system by XRD, ${ }^{57}$ Fe Mössbauer and vibrational spectroscopies. J. Mol. Struct., 1999, 480-481, P. 627-631.

[32] Štefanić G., Gržeta B., Musić S. Influence of oxygen on the thermal behavior of the $\mathrm{ZrO}_{2}-\mathrm{Fe}_{2} \mathrm{O}_{3}$ system. Mater. Chem. Phys., 2000, 65 (2), P. 216-221.

[33] Štefanić G., Gržeta B., Nomura K., et al. The influence of thermal treatment on phase development in $\mathrm{ZrO}_{2}-\mathrm{Fe}_{2} \mathrm{O}_{3}$ and $\mathrm{HfO}_{2}-\mathrm{Fe}_{2} \mathrm{O}_{3}$ systems. J. Alloys Compd., 2001, 327 (1-2), P. 151-160.

[34] Jiang J.Z., Poulsen F.W., Mrup S. Structure and thermal stability of nanostructured iron-doped zirconia prepared by high-energy ball milling. J. Mater. Res., 1999, 14 (4), P. 1343-1352.

[35] Cao W., Tan O.K., Zhu W., et al. An amorphous-like $x \alpha-\mathrm{Fe}_{2} \mathrm{O}_{3}-(1-x) \mathrm{ZrO}_{2}$ solid solution system for low temperature resistive-type oxygen sensing. Sens. Actuators, B, 2001, 77 (1-2), P. 421-426.

[36] Kiminami R.H.G. The monoclinic-tetragonal phase transformation of zirconia in the system $\mathrm{ZrO}_{2}-\mathrm{Fe}_{2} \mathrm{O}_{3}$. J. Mater. Sci. Lett., 1990, 9 (4), P. 373-374.

[37] Bohé A.E., Andrade Gamboa J.J., Pasquevich D.M. Enhancement of the martensitic transformation of tetragonal zirconia powder in the presence of iron oxide. Mater. Sci. Eng., A, 1999, 273-275, P. 218-221.

[38] Maglia F., Anselmi-Tamburini U., Spinolo G., Munir Z.A. Thermal Stability of Combustion-Synthesized Metastable Solid Solutions of Zirconia and Transition Metals. J. Mater. Synth. Process., 1999, 7 (5), P. 327-332.

[39] Garcia F.L., de Resende V.G., De Grave E., et al. Iron-stabilized nanocrystalline $\mathrm{ZrO}_{2}$ solid solutions: Synthesis by combustion and thermal stability. Mater. Res. Bull., 2009, 44 (6), P. 1301-1311.

[40] Pozhidaeva O.V., Korytkova E.N., Drozdova I.A., Gusarov V.V. Phase state and particle size of ultradispersed zirconium dioxide as influenced by conditions of hydrothermal synthesis. Russ. J. Gen. Chem., 1999, 69 (8), P. 1219-1222.

[41] Patterson A.L. The Scherrer formula for x-ray particle size determination. Phys. Rev., 1939, 56 (10), P. 978-982.

[42] Semenov V.G., Moskvin L.N., Efimov A.A. Analytical potential of Mössbauer spectroscopy. Russ. Chem. Rev., 2006,75 (4), P. $317-327$.

[43] Suzdalev I.P. Electrical and magnetic transitions in nanoclusters and nanostructures. KRASAND, Moscow, 2012,480 p. (in Russian)

[44] Gusarov V.V., Egorov F.K., Ekimov S.P., Suvorov S.A. Mössbauer study of the kinetics of the formation of film states in the interaction of oxides of magnesium and iron. J. Phys. Chem., 1987, 61 (6), P. 1652-1654. (in Russian)

[45] Gusarov V.V., Malkov A.A., Malygin A.A., Suvorov S.A. Thermally activated transformations of 2D nonautonomous phases and contradiction of polycrystalline oxide materials. Inorg. Mater., 1995, 31 (3), P. 320-323.

[46] Gusarov V.V., Suvorov S.A. Melting points of locally equilibrium surface phases in polycrystalline systems based on a single volume phase. J. Appl. Chem. of the USSR, 1990, 63 (8), P. 1560-1565. 